
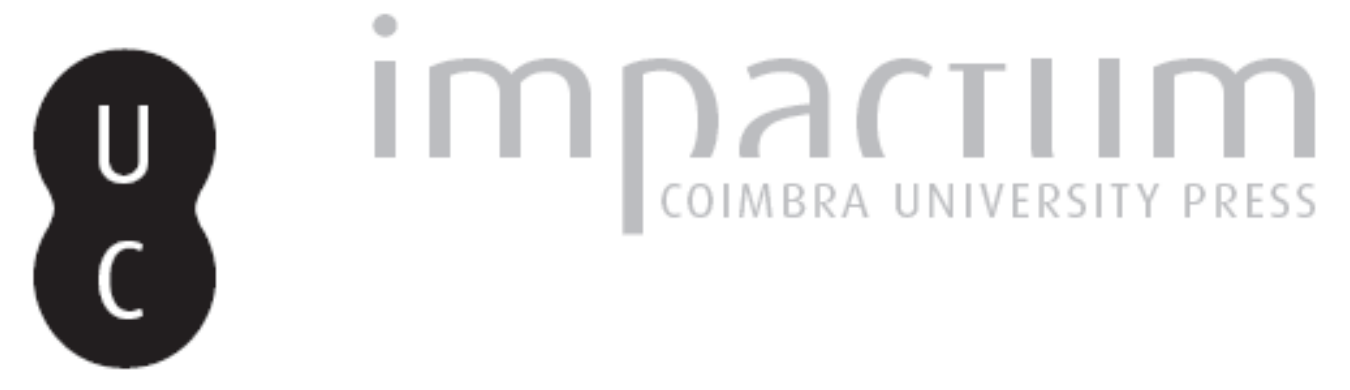

\title{
Neighbourhood: a threatened heritage in contemporary Europe
}

Autor(es): $\quad$ Grande, Nuno; Cremascoli, Roberto

Publicado por: Editorial do Departamento de Arquitetura

URL persistente:

URI:http://hdl.handle.net/10316.2/43467

DOI:

DOI:https://doi.org/10.14195/1647-8681_8_10

Accessed : $\quad$ 26-Apr-2023 15:59:02

A navegação consulta e descarregamento dos títulos inseridos nas Bibliotecas Digitais UC Digitalis, UC Pombalina e UC Impactum, pressupõem a aceitação plena e sem reservas dos Termos e Condições de Uso destas Bibliotecas Digitais, disponíveis em https://digitalis.uc.pt/pt-pt/termos.

Conforme exposto nos referidos Termos e Condições de Uso, o descarregamento de títulos de acesso restrito requer uma licença válida de autorização devendo o utilizador aceder ao(s) documento(s) a partir de um endereço de IP da instituição detentora da supramencionada licença.

Ao utilizador é apenas permitido o descarregamento para uso pessoal, pelo que o emprego do(s) título(s) descarregado(s) para outro fim, designadamente comercial, carece de autorização do respetivo autor ou editor da obra.

Na medida em que todas as obras da UC Digitalis se encontram protegidas pelo Código do Direito de Autor e Direitos Conexos e demais legislação aplicável, toda a cópia, parcial ou total, deste documento, nos casos em que é legalmente admitida, deverá conter ou fazer-se acompanhar por este aviso.

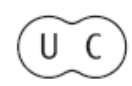




\section{Nuno Grande / \\ Roberto Cremascoli \\ COR architects \\ Neighhbourhood: A 'T'hreatened \\ I-Ieritage in Contemporary Europe}




\section{Identity crisis $^{1}$}

Europe is experiencing troubled times in the face of ongoing geopolitical changes inside and outside its geographic space. As it is known, this space has changed over the last few decades, based on a process driven by the European Union's economic optimism, which has always seen its enlargement as an opportunity to extend the Eurozone and the Schengen Area to new countries and people, fostering transnational investment and trade in the context of globalization. In this process, cultural and social issues seem to have always been in the background; that is, the European Union grew geographically, politically and economically without ever critically reflecting on the impact of its multiple internal identities' growth. The recent and troubled reaction to the wave of Middle East refugees, the reappearance of nationalist sentiments in many countries, and the progressive ethnic and religious intolerance in many urban settings openly expose the absence of such cogitation. Nowadays, the European crisis is essentially an identity crisis.

However, currently and more than ever, there is a desire to safeguard Europe's historical identity (its cities' exceptional heritage, architecture, monuments and treasures), which dominates the "politically correct" discourses of the Old Continent rulers, from Eurocrats to national leaders, from asset managers to city mayors. Yet, it must be asked how this discourse on heritage (centred on the value of spaces, buildings and objects) can extend to human values represented by the old and new inhabitants of European cities, given the increasing processes of migration and cultural diversity? And what social heritage should we protect in view of such phenomena as "ghettoization", "gentrification" and "touristification" in these cities? The defence mechanisms of the material heritage are presently insufficient to preserve the significant European intangible heritage: people and their citizen relations, gradually conquered throughout history, based on values of proximity, tolerance and multiculturalism; in brief, on the basis of the "neighbourhood" exercise, a concept intrinsically linked to the idea of Europe. The identity crisis described above, which has fuelled protectionist, nationalist, racist and xenophobic visions and actions in many countries, is essentially a neighbourhood crisis in European cities.

\section{The challenge of the Venice Biennale}

By contrast, Europe has always promoted spaces to show and allow multidisciplinary debate on its civilizational, technological and artistic achievements. The Great International Exhibitions and the famous Art and Architecture Biennales are part of this legacy of display and reflection that comes from the $19^{\text {th }}$ century. The Venice Biennale is a prominent example of this situation and it was precisely within the framework of this global stage that we have decided, as architects and architecture curators, to test the "neighbourhood" theme. After all, what better place to question social and cultural
Frontispiece (Fig. 1) Interior of the Portuguese Pavilion at the XV Venice Architecture Biennale, 2016 (@ Nicolò Galeazzi). 
Fig. 2 Álvaro Siza visits a resident of the neighbourhood that he designed in Campo di Marte, Giudecca Island, Venice (৫) Nicolò Galeazzi).
European identities than in the quintessential "World Heritage City" of Europe? Responding to the invitation of the Ministry of Culture of the Portuguese Government to curate the contents of the Portuguese Pavilion at the XV Venice Architecture Biennale, in 2016, we have decided to make a proposal that interacted directly with the physical and social fabric of that city, simultaneously showing what occurs in other European contexts.

In view of the impossibility of having the Portuguese Pavilion at the heart of the Biennale (in the Giardini or Arsenal areas, where Portugal has no official space), our suggestion was to locate it in an unpredicted place in Venice, where the Portuguese representation could arouse the interest of the remaining Venetians. The chosen space was Campo di Marte, on the Giudecca Island, less pressured by the touristic and artistic frenzy brought about by the Biennale.

The idea for the Pavilion's theme came from a simple but very significant fact we wanted to discuss: since 1985, the renowned Portuguese architect Álvaro Siza coordinates an urban renewal plan at the east end of this island, a process that has suffered numerous setbacks. An integral part of that plan is a social housing project, whose construction was halted in 2010 due to the builder's bankruptcy. When we proposed to occupy this site under construction, by installing the Portuguese Pavilion inside the suspended worksite, it immediately became a motive of interest for the promoters of the project (ATER, the Italian Institute for Social Housing) but also of debate among the neighbours of Campo di Marte on the municipality's responsibility for the slow urban renewal of the island. Unexpectedly the request of the Portuguese Government to set up its pavilion in that particular site triggered the process of completion of Álvaro Siza's social housing project by the local authorities.

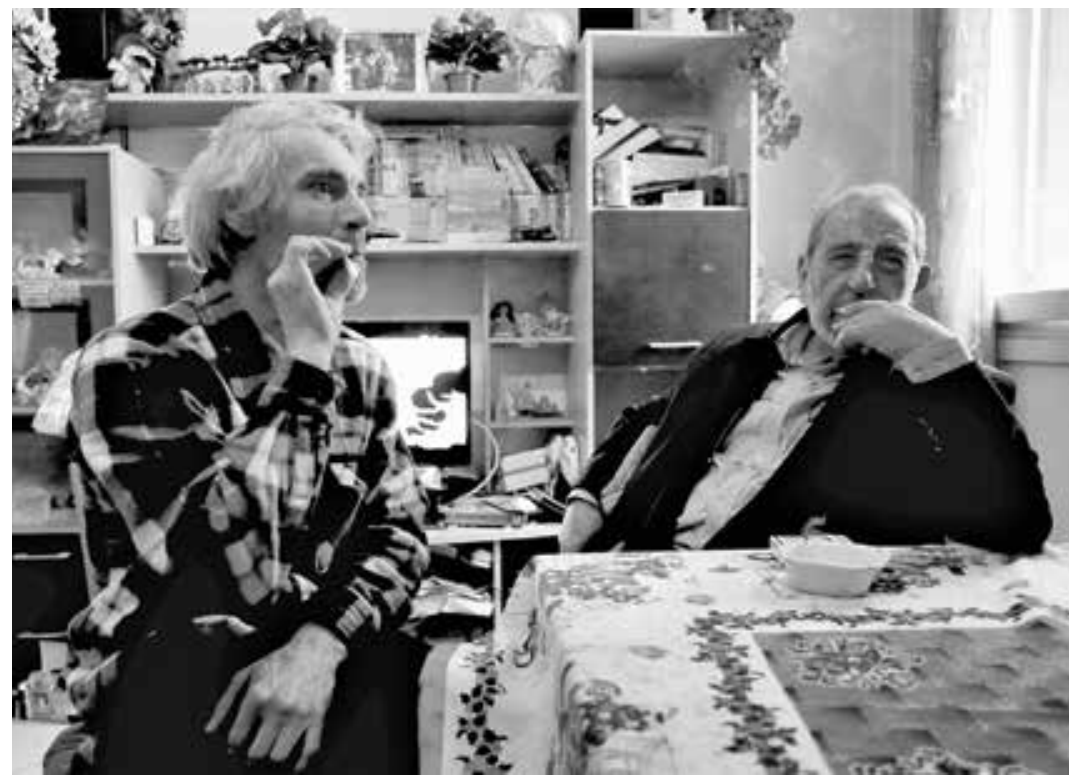


In that same vein, Álvaro Siza's plan and project for Giudecca provided the basis for the Portuguese Pavilion's theme: to narrate the remarkable relationship of this architect with different urban cultures, showing how over more than 40 years he designed his social housing districts in cities as different as Venice, The Hague, Berlin and Porto. Our ultimate goal was to demonstrate how Siza was able to build real European neighbourhoods and, in a reverse reading, to assess the extent to which they are also subject to the crisis of neighbouring values in Europe.

The theme presented by Portugal responded directly to the challenge posed by the general curator of the 2016 Venice Biennale, the Chilean architect Alejandro Aravena, to the various countries present at the event, in order to report real cases, existing on different urban fronts (Reporting from the front), and in which the action of the architect has proved decisive for the life of the population.

Finally, adding to all these references, the Portuguese Pavilion celebrated Álvaro Siza's long-lasting connection with Italian culture and especially with Siza's contemporary architect Aldo Rossi (1931-1997); with whom Siza learned how to read the historical city from its long-time "invariants" and "collective memories", concepts explained by the Italian architect in the remarkable book The Architecture of the City (1966). Siza assigned to Rossi, as early as 1986, a portion of his plan for the Campo di Marte in Venice, in which Rossi designed one of his last buildings.

Therefore, the Portuguese presence at the 2016 Venice Architecture Biennale was named Neighbourhood: where Alvaro meets Aldo, regaining the idea that being a "neighbour" in any European city allows us the opportunity to enjoy the inspiring encounter with the "other", who so often comes from another geography, from another culture.

\section{The neighbour Álvaro}

The Portuguese representation at the Venice Biennale of 2016, as it is easily understood, surpassed its condition of simply being an architecture display to give rise to a manifesto on the concept of "neighbourhood". Between May and November 2016, the models, sketches and technical drawings of four neighbourhoods of Álvaro Siza were represented in various forms; but within the exhibition space, within that architectural work under construction, each of these places emerged as a "microcosm" of European cultural and social heritage.

That vision was only made possible because we have invited Álvaro Siza to return, decades later, to those cities he knew, and those districts he designed, analysing their evolution as a reflection of those societies' transformation. The challenge, which Siza accepted with great kindness, led us to travel in his company between January and March 2016, through the districts of Venice (Campo di Marte), The Hague (Schilderswijk), Berlin (Schlesisches Tor) and Porto (Bouça Neighbourhood). 
The whole journey was covered by a team of television and print media reporters, coordinated by the journalist Cândida Pinto (SIC / Expresso), who used the extensive material captured in video and photography during the visits to produce four videos for the Portuguese Pavilion. Nevertheless, these documentaries were aimed at a wider audience because they are part of the series "Vizinhos (Neighbours)", screened on the television channel SIC Notícias.

In these recordings, we may observe (in a rare gesture in the international architectural panorama) a famous Pritzker architect walking through those quarters, being confronted with the unusual changes of his work, entering the houses he designed, talking to the residents, listening to their stories and their complaints. In all those moments Álvaro has become one of their neighbours.

We will thus analyse how this experience enabled us to understand and discuss the issues that threaten today's neighbouring relations in Europe $^{2}$.

\section{Beyond Venice's "touristification"}

Álvaro Siza's project for the Campo di Marte area resulted from a restricted invitation to an architecture competition, launched in the mid-1980s, for a very decrepit (and partially demolished) residential area of the Giudecca Island. Álvaro Siza designed an harmonious urban fabric, based on the long structure of the old cadastre, delineated from north to south, between the Giudecca Canal and the Lagoon, and returning to some of the architectural archetypes existing on this island: galleries, porticos, patios, loggias. To this end, he carefully studied the urban analysis developed by Egle Trincanato (researcher at the Istituto Universitario di Architettura di Venezia), in her seminal book Venezia Minore, published in 1948. From that study he learned how to identify the typological invariants of this popular housing fabric, which formed the interior of the Giudecca Island, and from which emerged, by contrast, the churches and palaces placed at the borders of the canal and the lagoon. Acknowledging this influence, Siza opted for a cohesive urban composition in his general plan, based on height uniformity and windows arranged in a constant rhythm along the extensive facades. Only a part of this set of structures was built, which include projects by Álvaro Siza (one part until now), Aldo Rossi and Carlo Aymonino (blocks already finished).

Upon returning to Campo di Marte in February 2016, Siza met some of the residents living in the finished building of his project. The meeting made him understand how the population had appropriated these built typologies, but also the collective spaces. He visited, talked, smoked and drank with several neighbours throughout a cheerful afternoon of conviviality. There he heard, in local dialect, that Giudecca is the last island where the authentic Venetians live, in contrast to the accelerated "touristification" of the central island around the Grand Canal. In Campo di Marte, Siza realised how worth it was studying the 


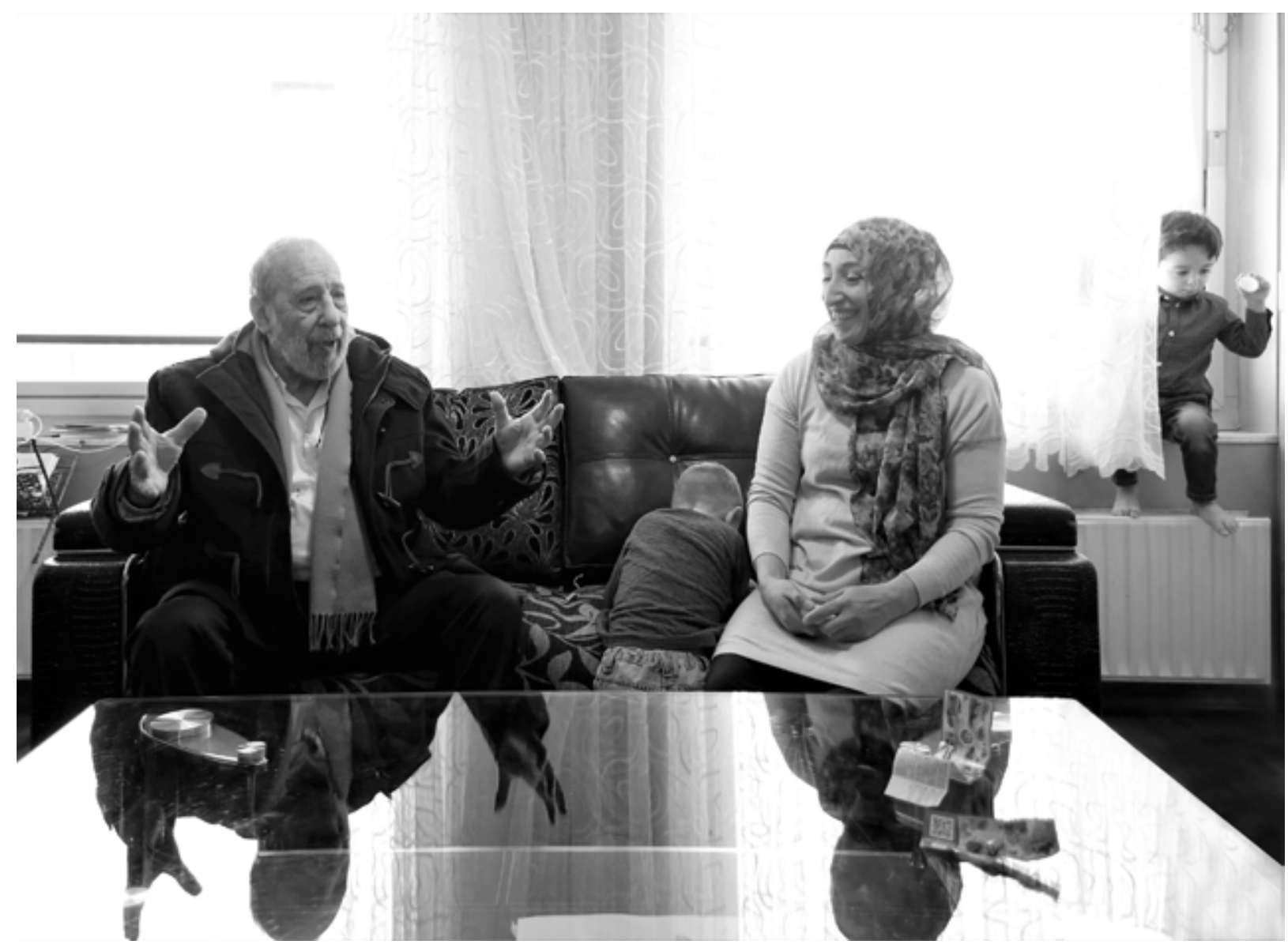

Fig. 3 Álvaro Siza visits a resident of the neighbourhood that he designed in Schilderswijk, in The Hague (@ Nicolò Galeazzi).

urban form and the social life of this Venezia Minore, where it is still possible to build true neighbourly ties.

\section{The "ghettoization" of social housing in The Hague}

In 1984, Álvaro Siza was invited by the municipality of The Hague to redesign a derelict and stigmatised area of the city - the district of Schilderswijk - and build new social housing in it. In this neighbourhood lived, in equal proportion, Dutch and immigrant families, mainly from Turkey, Morocco, Cape Verde and Suriname. After visiting the quarter and listening to the inhabitants' wishes, together with a team of social workers, Álvaro Siza designed two construction phases: the Punt Komma area (1986-1989) and the Jacob Catsstraat area (1989-1993). In both, he took up the morphology of the city's historic blocks, using their more common cladding, the brick, and recreated a traditional access space to the buildings from the street: the Haagse Portiek. This portico allows, through a wide exterior staircase, to have access to a common landing for the apartments' entrances. This "culturalist" revisit to the history of The Hague was accompanied by the creation of flexible housing typologies, 


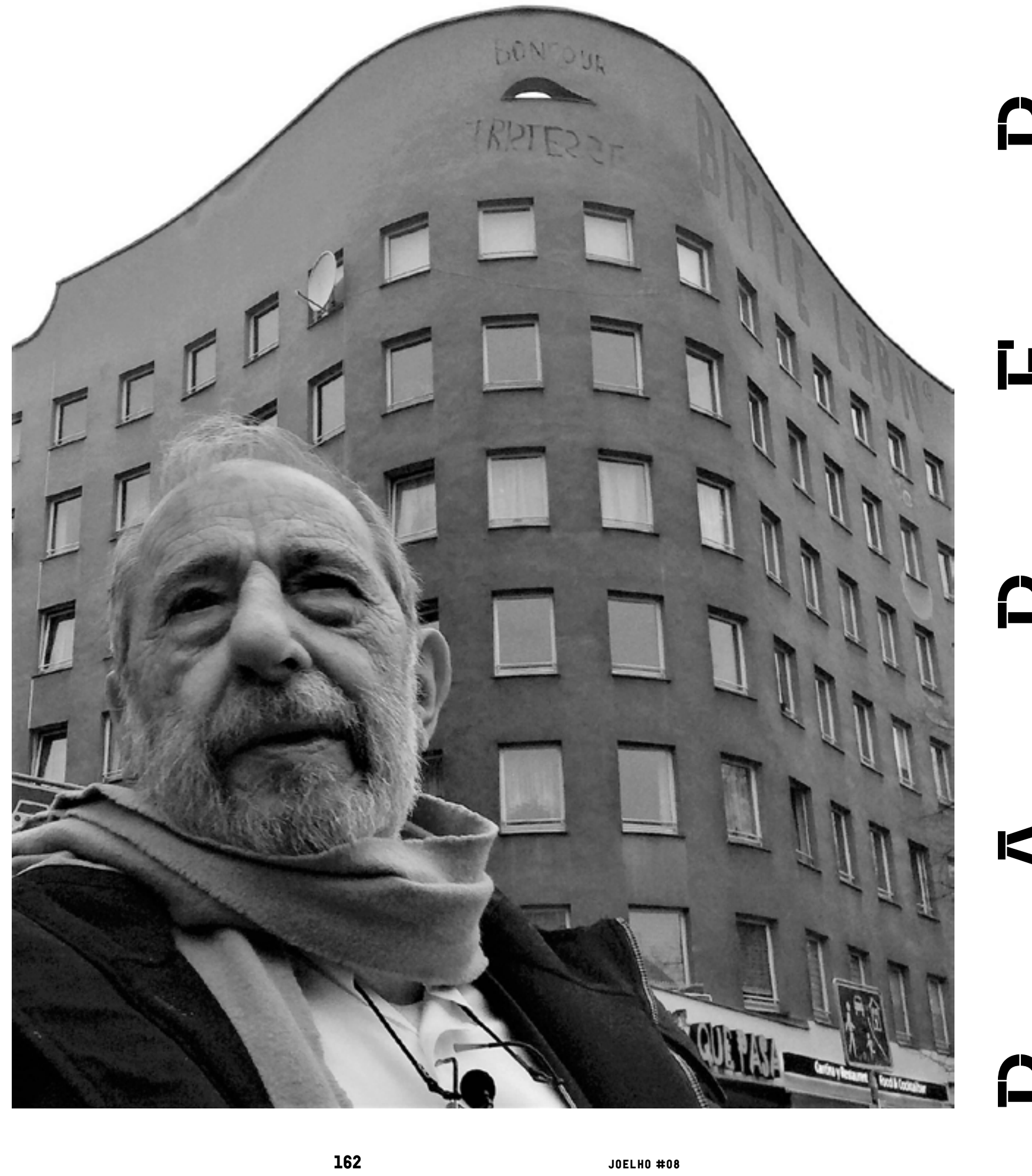


adapted to different family experiences and without spatial discrimination regardless of the cultural or religious origin of their inhabitants.

Siza's proposal was previously debated with neighbours of all origins, based on simulations of the interior spaces, carried out on a real scale, with which everyone was able to know the new apartments' layout and suggest possible changes, in a participatory method of true social empowerment.

In March 2016, we have returned with Álvaro Siza to the district of Schilderswijk, in the company of members of the old municipal council, and visited some Turkish, Syrian and Moroccan families who have settled there for the last 25 years. After crossing the Haagse Portiek, the group entered several houses, took off their shoes and sat comfortably in the living rooms, talking to the families and drinking tea. They told us that the Dutch vox populi has been disparaging the neighbourhood, considering it a ghetto and describing it as the "Sharia Triangle" (nowadays 90\% of its population is Islamic). However, on that particular day, it was made clear to all of us that the so-called "ghettoization" of this district is, first of all, an argument of the more conservative political rhetoric, wielded by the Dutch right-wing factions. In Schilderswijk, good neighbourly relations are maintained and recommended.

\section{The gentrification of the reunited Berlin}

When Álvaro Siza visited Berlin in the late 1970s, the city had been enclosed for more than fifteen years by a physical and political Wall, one of the main symbols of the Cold War. Still marked by the wounds of World War II, Berlin was then beginning its "critical reconstruction" within the framework of the urban planning process IBA (Internationale Bauausstellung, 1979-1987). In that process, Siza presented an urban renewal proposal for one block at Schlesisches Tor, in Kreuzberg. This was an historic neighbourhood on the outskirts of West Berlin, close to the Wall, characterised by a changing population, partly due to the arrival of Turkish immigrants and young squatter artists.

Siza won the competition in 1980 , based on a project that crucially interpreted the fragments and urban voids left by the war destruction, trying to combine them into a sensitive composition which did not completely rebuild the block, but rather allowed the discovery of its interior richness. Similarly, and avoiding excessive "social sanitization", Siza integrated some of the inhabitants' main ambitions by proposing two social equipments at the heart of the neighbourhood: a Nursery School and a Day Centre for the elderly. At last, in one of the corners of Schlesisches Strasse, the Portuguese architect designed a sevenstorey residential building, once again learnt from the surrounding architectural richness. He diversified the housing typologies, making them flexible according to the social and cultural multiplicity of its inhabitants. An ironic, literary-inspired graffiti painted on the curved parapet of the building - Bonjour Tristesse - would inscribe the
Fig. 4 Álvaro Siza visits the building dubbed Bonjour Tristesse, which he designed, in the 1980s, for the Kreuzberg district, in Berlin (c) Nuno Grande). 
neighbours' first critical "appropriation", by questioning the regular design of the windows and the melancholy colour of the facades.

In March 2016, thirty years after the completion of this project, we have returned with Álvaro Siza to Kreuzberg. We walked through the Nursery gardens, climbed to the roof of the Day Centre and were greeted with a warm welcome by the elder users. In the Bonjour Tristesse building, today in slow rehabilitation, we have found some of its first residents, of Turkish origin, but we have realised that the property is in a process of cultural and social gentrification. Bought by an Austrian real estate fund, its apartments and shops now receive new tenants: thematic restaurants on the ground floor, architects, designers, actors and filmmakers on the upper floors; in most cases at the expense of the expulsion of pre-existing families and activities. In fact, Kreuzberg, once peripheral, has become the centre of the cosmopolitan life of the reunified Germany new capital. The Berlin Wall fell almost thirty years ago; new neighbours have occupied the district ever since, without necessarily creating true meanings of neighbourhood.

\section{Inter-classist crossings in the centre of Porto}

In the Portuguese summer of 1974, just three months after the April 25th Revolution, Nuno Portas, then Secretary of State for Housing and Urban Development, launched a governmental dispatch named SAAL (Serviço de Apoio Ambulatório Local / Local Ambulatory Support Service), which allowed the most deprived inhabitants to organise themselves and politically fight for the "right to housing" and for the "right to the city", that is, to remain in their places of origin or settlement. This programme led to the creation of housing projects designed by different architects, in an ongoing dialogue with the various residents' associations, established in the meantime. In Bouça, at the centre of Porto, many plots were then squatted by the population, a fact which would directly involve Álvaro Siza, author of a housing project intended for that quarter. Receptive to the new demands of the Bouça squatters, the architect readjusted his project so it could include a greater number of deprived residents.

Siza's proposal was based upon a double historical revisit: on the one hand he interpreted the forms and spaces of the old popular districts of Porto: the ilhas; on the other hand, he evoked learned models of working-class housing, developed by European modern architecture avant-gardes in the 20s and 30s. This fusion resulted in the "first life" of the Bouça Neighbourhood. Between 1975 and 1976, two blocks of flats were built, with four floors (2 duplex), with direct entrances from the street or from a raised gallery. Community relations were then established in the daily use of the different extended courtyards between the housing blocks, some marked by a succession of multi-functional outdoor stairs. The project was suddenly interrupted at the end of the 70s decade with the cessation of the SAAL programme. Since then, social housing policies passed into the municipalities' administration, in an electoral representation 

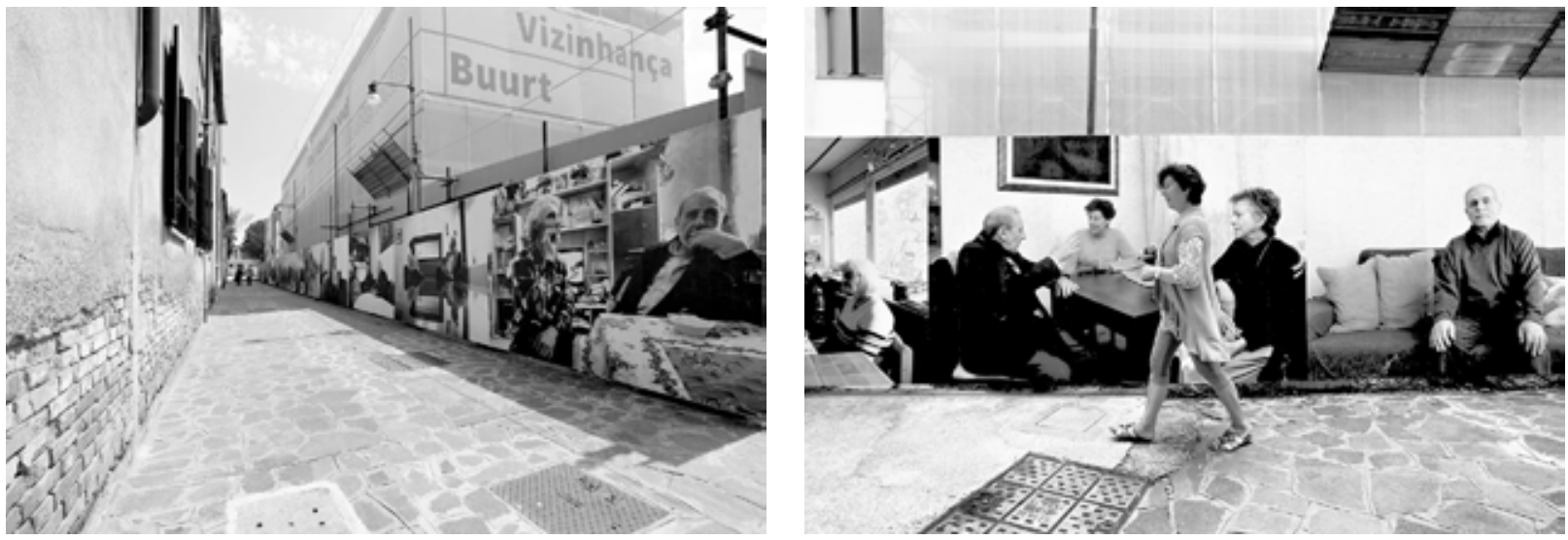

system opposing the participatory democracy models, which had characterised the previous revolutionary process. For twenty years, the neighbourhood remained "amputated" and progressively derelict until the residents' association, in conjunction with another housing cooperative, proposed to the municipality to complete the project by Álvaro Siza. This action made possible to resume the work, giving opportunity to the author to finally demonstrate the sense of architectural adjustment and urban integration of his proposal. The neighbourhood's completion, inaugurated in 2006, inevitably brought new residents of different social and cultural conditions to the houses.

In 2016, a decade after the quarter's conclusion, Álvaro Siza visited the area and several residents' houses and questioned them how they lived inside those walls. There he met again some of the first inhabitants who, with his support, had fought for the founding of the residents' association in 1974. He heard their complaints about the construction completion process and how many of their fellow members had not wanted or been able to return to the houses that were meant to them. During other visits, Siza observed that the gentrification process was present at the neighbourhood by meeting young architects, designers and artists, who became the owners of those houses placed on the market by the housing cooperative. Avoiding any false moralism, Álvaro Siza realised that the district was no longer just part of his revolutionary imaginary of 40 years ago, but had become an inter-classist, inter-cultural and inter-generational fragment of the contemporary city. What better conditions, after all, to generate a real neighbourhood?

\section{A Europe made of neighbours}

The multiple experiences and issues we have just described were documented inside and outside the Portuguese Pavilion at the 2016 Venice Architecture Biennale, questioning those who passed through Campo di Marte to reflect on their own "neighbour" status. In the exterior palisade surrounding the building under construction, large-
Fig. 5 and 6 Exterior of the Portuguese Pavilion at the XV Venice Architecture Biennale, 2016 (৫) Nicolò Galeazzi). 
scale photographs taken from the four journeys invited the passersby to "enter" the household environments visited by the architect and understand those citizens' life. Giudecca was thus "inhabited" by residents of The Hague, Berlin and Porto, and often we were able to observe the giudeccini facing their own portrayed environments. There was a sense of sharing that goes beyond geographies, cultures, religions or social conditions; there unfolded a Europe made up of neighbours.

The new palisade replaced another one, worn out by time, but where the community protest graffiti about the urban renewal of Campo di Marte, which had come to a standstill, were visible. This palisade was reused to overlay the inside walls of the Portuguese Pavilion, giving voice to the local neighbours. Some of the slogans on those panels stated: "No to evictions!"; or "Disgraceful, enough of speculation!"; or "The houses for those who need them!". They could actually have been written in any of the neighbourhoods and times depicted by the exhibition.

As we have noted, Álvaro Siza's professional career has been characterised by constant political and social conflicts' management, and he is the only Pritzker warded architect developing extensive social housing programmes in different European contexts and, more than that, wanting to debate the subject openly. This determination derives from his humanistic and universal understanding of European culture, resulting from the contact with disadvantaged or socially uprooted people, in particular ethnic minorities of different cultural backgrounds. Without ever being paternalist or moralist, Siza has always refused to design exclusive spaces to each of these ethnic groups, preferring to find common typological denominators where the same type of ambience may fulfil the needs of diverse inhabitants. This implies, on his part, a perceptive observation of the local living conditions.

Siza's social districts are now subject to phenomena that pose new problems to already established neighbouring relations. Venice's accelerated "touristification" will undoubtedly reach the local leases on the island of Giudecca, which may lead to the inhabitants' exodus of one of the few places where those ancestral relations still remain. The "ghettoization" of the Schilderswijk neighbourhood in The Hague is part of the political polarisation that is now being experienced in Northern Europe, as a consequence of the nationalism resurgence and the gradual ostracisation of Islam, seen by many xenophobic Dutch as the main origin of jihadism. The gentrification of the Kreuzberg neighbourhood in Berlin, or the Bouça neighbourhood in Porto, can generate, as we have seen, different results: the expulsion of the local populations and the replacement of proximity relations for more impersonal ones; or, at the other end, a new mixture of neighbours of different generations, cultures and social conditions, in an unstable but possible equilibrium.

European city centres are increasingly becoming spaces designed for city users and less and less for city tenants. In many of these centres, the sense of "belonging" is being replaced by totally uprooted tourist 
experiences (like the uncritical and unregulated growth of the Airbnb phenomenon) or by totally precluding sectarian and safe experiences (like the proliferation of so-called "private condominiums").

It is crucial to revive the healthy exercise of "neighbourhood" as a contribution to overcome Europe's current identity crisis. To accomplish this rescue, it will be necessary to look at many of its historical and contemporary districts, as those of Álvaro Siza, where we still find strongholds of this citizenship exercise. On those neighbourhoods lies, we are certain, this Europe of many identities, made up of multiple neighbours.

\footnotetext{
$1 \rightarrow$ This text is supported by the Portuguese Foundation for Science and Technology (FCT - Fundação para a Ciência e a Tecnologia) under the Strategic Project (UID/SOC/50012/2013). It was originally published in Portuguese in Revista Património, $n^{\circ}$ 4, 2016, edited by Direção Geral do Património Cultural do Ministério da Cultura, and is the result of the research carried out by its authors as curators of the Portuguese Pavilion in the XV Venice Architecture Biennale.

$2 \rightarrow$ The cases' description is based on the curators' texts written for the Portuguese Pavillon exhibition at the Venice Biennale of 2016. Refer to: Nuno Grande and Roberto Cremascoli, Vizinhança. Onde Álvaro encontra Aldo/ Where Alvaro meets Aldo. Lisbon/Berlin: Hatje Cantz, 2017.
} 